\title{
Pengembangan Desain Interior Minibus untuk Shuttle Travel Rute Bandara
}

\author{
Katon Ageng Rezkita dan Bambang Tristiyono \\ Departemen Desain Produk, Fakultas Arsitektur Desain dan Perencanaan, \\ Institut Teknologi Sepuluh Nopember (ITS) \\ e-mail: gacombi@prodes.its.ac.id
}

\begin{abstract}
Abstrak - Shuttle travel dengan rute bandara adalah layanan jasa transportasi, baik dari bandara ke berbagai kota maupun sebaliknya yang menggunakan kendaraan jenis minibus. Perkembangan inovasi dalam bisnis shuttle travel mengalami stagnansi dalam pelayanannya, baik servis maupun kualitas interior kendaraan, sedangkan orientasi konsumen perlahan berubah dari yang dulunya harga menjadi kualitas. Mengacu pada target konsumen pra- dan pasca-penerbangan, shuttle travel rute bandara memiliki kebutuhan-kebutuhan spesifik, seperti storage interior yang memadai dan desain interior yang nyaman. Namun, kebutuhan untuk meningkatkan pelayanan ini tidak dapat dipenuhi oleh interior minibus produksi karoseri yang ada. Melihat permasalahan tersebut, konsep comforting dan organized diimplementasikan pada desain interior minibus ini berdasarkan brainstorming idea dan analisis user yang telah dilakukan. Konsep comforting mencakup perlakuan spesifik kepada user dimana interior minibus menawarkan driving experience yang baik dan berbeda. Selain itu, konsep organized mencakup konfigurasi interior secara menyeluruh baik dari kursi penumpang hingga storage dan bagasi. Penelitian ini bertujuan untuk menghasilkan desain interior minibus yang sesuai dengan kebutuhan spesifik user-nya. Metode pengumpulan data yang digunakan adalah in-depth interview dan tinjauan berbagai literatur. Beberapa studi dan analisis yang berhubungan dengan konfigurasi interior, kenyamanan berkendara, impresi desain interior, hingga penerapan teori jarak dan ruang antar individu dilakukan dalam perancangan interior minibus ini.
\end{abstract}

Kata Kunci-shuttle travel, driving quality, organized..

\section{PENDAHULUAN}

$\mathrm{S}$ HUTTLE TRAVEL datangnya adalah layanan transportasi dengan sistem layanan antar-jemput antar-kota atau antarpropinsi dengan jarak tempuh maksimum ideal $150 \mathrm{~km}$ per perjalanan (one-way trip), menggunakan kendaraan minibus dengan kapasitas maksimum 9-15 tempat duduk [1]. Shuttle travel rute bandara sendiri adalah jenis layanan transportasi darat yang memberikan jasa angkutan dengan cara mengumpulkan penumpang pada suatu titik pool (bandara) ke kota tujuannya dengan menerapkan layanan dengan rute tetap dan terjadwal secara reguler. Perusahaan shuttle travel dituntut untuk memiliki strategi demi menjadi perusahaan terbaik dalam bisnis tersebut, yang dapat memberikan nilai dan tingkat kepuasan maksimal kepada konsumennya, dengan mengetahui apa saja yang menjadi preferensi konsumen dalam memilih jasa shuttle travel.

Kualitas interior kendaraan shuttle travel merupakan salah satu faktor penting yang mempengaruhi preferensi konsumen. Kebutuhan bisnis shuttle travel rute bandara untuk meningkatkan pelayanannya dari segi kualitas interior kendaraan tidak dapat terpenuhi oleh minibus produksi karoseri karena minim fitur khusus yang sesuai dengan kondisi user shuttle travel rute bandara. Mengacu pada target user pradan pasca-penerbangan dengan kondisi fisik dan barang bawaannya, fitur khusus tersebut meliputi desain interior yang nyaman dan konfigurasi interior beserta bagasi yang memadai.

Kursi penumpang yang tidak sesuai dengan anthropometri penumpang dapat menyebabkan penumpang cepat mengalami kelelahan, perasaan tidak nyaman dalam perjalanan, menimbulkan pegal-pegal dan rasa sakit pada anggota tubuh [2]. Kursi minibus dirancang dengan mempertimbangkan anthropometri orang Indonesia sehingga ketidaknyamanan yang dialami oleh penumpang dapat diminimalkan.

Teori proxemics yang menelaah persepsi manusia atas ruang (pribadi dan sosial), cara manusia menggunakan ruang, dan pengaruh ruang dalam komunikasi digunakan dalam pengambangan desain interior ini. Jarak atau ruang memiliki fugsi seperti safety, communication, affection dan threat. Kebiasaan/kecenderungan penggunaan ruang muncul karena dorongan teritorial. Penggunaan ruang berhubungan erat dengan kemampuan bergaul dengan sesama dan penentuan keakraban antara diri dengan orang lain. Berdasarkan pengamatannya di Amerika Utara, Hall menentukan 4 zona jarak di mana manusia bergerak tersebut yaitu intimate space 0 - 18 inci $(<0,5 \mathrm{~m})$, personal space 18 inci - 4 kaki $( \pm 0,5 \mathrm{~m}-$ $1,5 \mathrm{~m})$, social space 4 - $10 \mathrm{kaki}(1,5 \mathrm{~m}-3 \mathrm{~m})$ dan public space 10 kaki - tidak terbatas $( \pm 3 \mathrm{~m})$.

Konsep pengerjaan dalam desain interior kendaraan yang dieksplorasi secara kuantitatif digunakan sebagai dasar untuk mengobservasi persepsi pelanggan terhadap interior kendaraan melalui survei. Daftar karakteristik interior kendaraan dan atribut pengerjaan seperti shape harmony, color harmony, pemilihan material, dan atribut lainnya dianalisis dengan menggunakan skala multidimensi, analisis cluster, dan dekomposisi. Pendekatan analitis ini dapat menjadi acuan pengerjaan desain yang memenuhi kepuasan pelanggan atas interior kendaraan berkualitas tinggi.

Dengan menggunakan berbagai data baik observasi langsung maupun literatur, pengembangan desain interior minibus dilakukan sehingga dapat menghasilkan desain dan konfigurasi interior yang sesuai dengan kebutuhan konsumen shuttle travel rute bandara. 


\section{II.METODOLOGI}

\section{A. In-depth Interview}

In-depth interview dilakukan kepada stakeholder terkait desain minibus ini, yaitu pihak perusahaan shuttle travel dan perusahaan second stage body manufacturer (karoseri) minibus. Interview terhadap perusahaan shuttle travel mencakup skala bisnis, rute dan intensitas, keuntungan dan biaya operasional, serta pengembangan fitur interior.

Untuk perusahaan karoseri, data yang diambil berupa aspek teknis manufaktur interior minibus, jenis dan dimensi sasis, serta harga produksi. Interview dilakukan pada tanggal 27 November 2017 di karoseri Dua Bersaudara Jl. Buduran No. 1, Sidoarjo, Jawa Timur.

\section{B. Literature Review}

Literaur atau jurnal didapat dari berbagai website. Dari metode pngumpulan data ini, didapat beberapa data yang dapat diaplikasikan pada perancangan ini, yaitu:

1. Data observasi preferensi konsumen terhadap jasa shuttle travel.

2. Panduan atau guide dalam mendesain interior kendaraan.

3. Perancangan passenger seat atas aspek ergonomi.

4. Proses desain interior kendaraan khususnya kendaraan jenis minibus.

\section{Eksplorasi Ide}

Ideasi dilakukan dengan thumbnail sketch bentuk dan proporsi yang mengacu dengan berbagai data yang telah diperoleh baik teknis maupun visual. Ideasi ini dilakukan untuk memunculkan ide-ide baru dalam pengembangan desain interior minibus.

\section{D.Desain Alternatif}

Hasil dari eksplorasi ide dikembangkan ulang sehingga didapatkan beberapa desain akhir. Desain-desain tersebut merupakan alternatif desain yang nantinya akan dipilih dengan mengukur sesuai parameter yang telah ditetapkan.

\section{E. Pengembangan Desain}

Dari desain alternatif yang ada, dipilih satu desain berdasarkan penilaian dari beberapa parameter yang telah ditetapkan. Kemudian, desain tersebut dikembangkan lagi secara lebih detil.

\section{F. Desain Final}

Desain final merupakan desain akhir yang disimulasikan secara digital beserta output berbagai gambar rendering operasional dan suasana.

\section{KONSEP DAN ANALISIS}

\section{A. Analisis Konsep Desain}

Melalui brainstorming, konsep desain didapatkan berdasarkan data aktivitas dan kebutuhan penumpang. Masingmasing konsep dideskripsikan secara objektif sehingga didapat ketentuan capaian desain yang perlu dipenuhi.

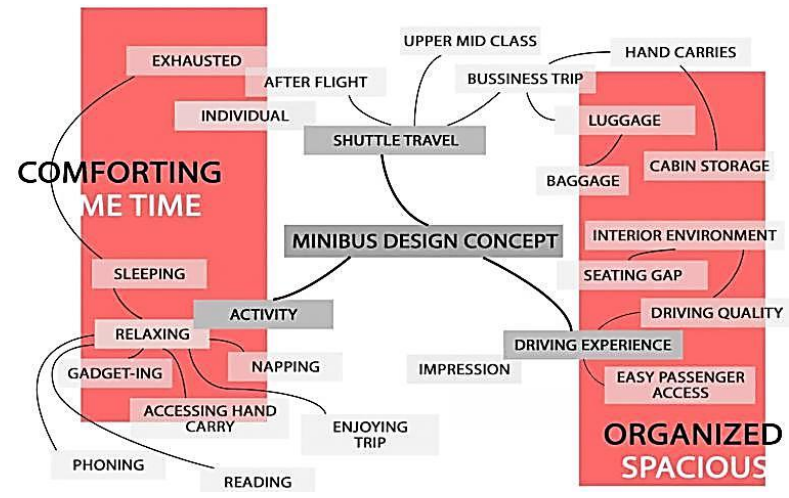

Gambar 1. Brainstorming Konsep Desain.

Tabel 1.

Objective Tree Concept

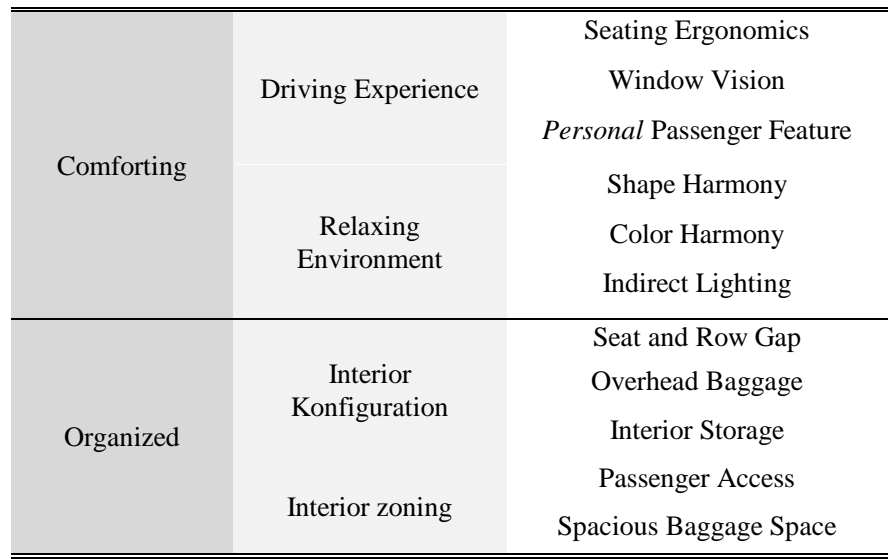

Dua konsep tersebut dijelaskan lebih lanjut sebagai berikut.

\section{1) Comforting}

Konsep comforting diarahkan pada kualitas berkendara yang dialami para penumpang selama perjalanan. Konsep diterapkan pada suasana desain interior secara keseluruhan sehingga dapat memberikan pengalaman berkendara yang berkesan relaxing.

2) Organized

Konsep organized diarahkan pada pengkonfigurasian dan zonasi interior secara menyeluruh demi memenuhi kebutuhan user yang spesifik. Organized yang diterapkan mencakup konfigurasi kursi, bagasi, storage interior, hingga akses koridor keluar masuk penumpang.

\section{B. Analisis User}

Meliputi psikografis konsumen, rumusan kebutuhan dan fitur, persona, serta barang bawaan pengguna layanan jasa shuttle travel rute bandara. Kesimpulan fitur yang perlu untuk diaplikasikan dapat dilihat pada Tabel 2.

\section{A. Analisis Zoning}

Dengan semua data dan kebutuhan desain yang diperoleh, pemilihan sasis berdasar komparasi sasis yang memungkinkan untuk digunakan dan pilihan jatuh pada Mitsubishi FE 84G.

\section{B. Analisis Dimensi Passenger Seat}

Analisis ini meliputi penetapan dimensi kursi, dan konfigurasinya. Dimensi kursi dihitung dengan data-data dari penelitian yang telah dilakukan sebelumnya. 
Tabel 2.

Perumusan Fitur Interior

\begin{tabular}{|c|c|c|c|}
\hline "Konsumen & & "Kebutuhan & Fitur \\
\hline \multirow[t]{2}{*}{$\begin{array}{l}\text { Usia } \\
\text { Produktif }\end{array}$} & Laki-laki & $\begin{array}{l}\text {-Charging Gadget } \\
\text {-Kesan Prestige } \\
\text {-Kabin Tidak } \\
\text { Bising } \\
\text {-Sinyal Internet } \\
\text {-Kenyamanan }\end{array}$ & $\begin{array}{l}\text {-Electrical Port } \\
\text {-Desain Prestige } \\
\text {-Kedap Suara } \\
\text {-Free Wi-fi } \\
\text {-Seat Armrest }\end{array}$ \\
\hline & Wanita & $\begin{array}{l}\text {-Membaca } \\
\text {-Nilai Privasi } \\
\text {-Barang Bawaan } \\
\text {-Kursi Nyaman } \\
\text {-Pemandangan Luar }\end{array}$ & $\begin{array}{l}\text {-Lampu Baca } \\
\text {-Gap Seat/Row } \\
\text {-Spacious Baggage } \\
\text {-Ergonomi Kursi } \\
\text {-Panoramic Roof }\end{array}$ \\
\hline \multirow[t]{2}{*}{$\begin{array}{l}\text { Usia } \\
\text { Lanjut }\end{array}$} & Laki-laki & $\begin{array}{l}\text {-Interior Nyaman } \\
\text {-Istirahat } \\
\text {-Penerangan Kabin } \\
\text {-Membawa Minum } \\
\text {-Bekerja }\end{array}$ & $\begin{array}{l}\text {-Kualitas Interior } \\
\text {-Driving Quality } \\
\text {-Interior Lighting } \\
\text {-Cup Holder } \\
\text {-Fold-out Table }\end{array}$ \\
\hline & Wanita & $\begin{array}{l}\text {-Kenyamanan Kursi } \\
\text {-Barang Bawaan } \\
\text {-Komponen Interior } \\
\text {-Storage Memadai } \\
\text {-Nilai Privasi } \\
\text {-Sirkulasi Udara }\end{array}$ & $\begin{array}{l}\text {-Adjustable Seat } \\
\text {-Konfigurasi } \\
\text { Bagasi } \\
\text {-BSR Compliance } \\
\text {-Storage } \\
\text {-Konfigurasi Kursi } \\
\text {-Personal AC } \\
\text { Knob }\end{array}$ \\
\hline
\end{tabular}

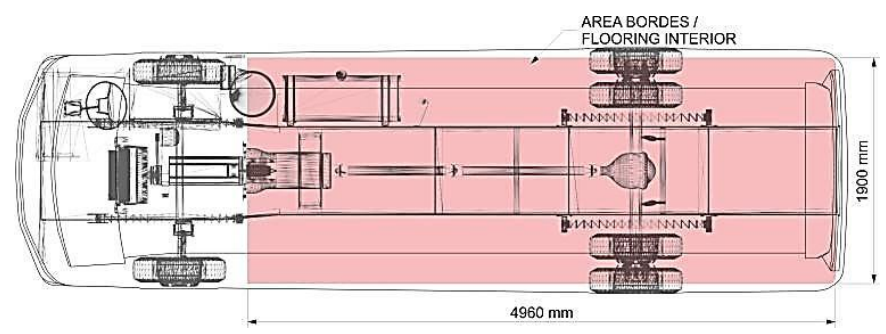

Gambar 2. Analisis Zoning Sasis Mitsubishi FE 84G.

Tabel 3.

Data Anthropometri

\begin{tabular}{clcc}
\hline \hline No & Data & Persentil & Ukuran \\
\hline 1 & Tinggi Popliteal & $50 \%$ & $440 \mathrm{~mm}$ \\
2 & Pantat Popliteal & $50 \%$ & $435 \mathrm{~mm}$ \\
3 & Lebar Bahu & $50 \%$ & $440 \mathrm{~mm}$ \\
4 & Tinggi Duduk Santai & $95 \%$ & $850 \mathrm{~mm}$ \\
5 & Tinggi Siku Posisi Duduk Santai & $50 \%$ & $250 \mathrm{~mm}$ \\
6 & Jarak Siku ke Tangan & $50 \%$ & $255 \mathrm{~mm}$ \\
7 & Jarak Pantat ke Lutut & $95 \%$ & $590 \mathrm{~mm}$ \\
\hline \hline
\end{tabular}

Tabel 4.

Formulasi Dimensi

\begin{tabular}{clcc}
\hline \hline No & Dimensi & Formula & Ukuran \\
\hline 1 & Tinggi Alas Kursi & TP + TOL & $450 \mathrm{~mm}$ \\
2 & Panjang Alas Kursi & PP & $430 \mathrm{~mm}$ \\
3 & Lebar Alas Kursi & LB & $440 \mathrm{~mm}$ \\
4 & Tinggi Sandaran Kursi & TDS & $850 \mathrm{~mm}$ \\
5 & Tinggi Sandaran Tangan & TSS & $250 \mathrm{~mm}$ \\
6 & Panjang Sandaran Tangan & JST & $265 \mathrm{~mm}$ \\
7 & Jarak Antar Kursi & JPL - PP + TOL & $200 \mathrm{~mm}$ \\
\hline \hline
\end{tabular}

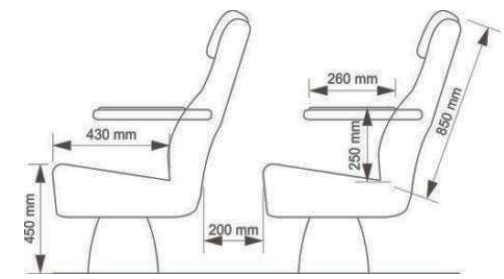

Gambar 3. Analisis Dimensi Passenger Seat.

\section{C.Analisis Konfigurasi Kursi berdasar Teori Proxemics}

Dari dimensi yang telah didapat dari analisis sebelumnya, pengkonfigurasian jarak antar kursi dan row dilakukan dengan mempertimbangkan aspek nilai proxemics.

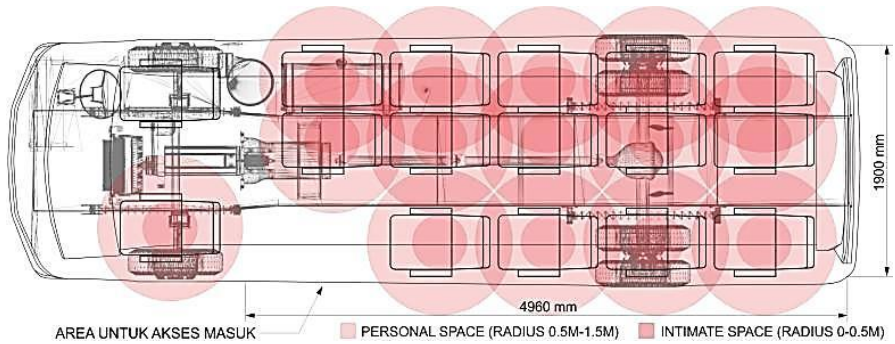
Gambar 4. Analisis Konfigurasi Kursi Berdasar Teori Proxemics.

\section{D.Analisis Akses Penumpang}

Analisis akses penumpang dilakukan dengan mempertimbangkan kemudahan akses naik-turun kendaraan. Dimensi koridor juga berdasarkan dimensi yang telah didapatkan dari analisa dimensi kursi dan konfigurasi kursi.

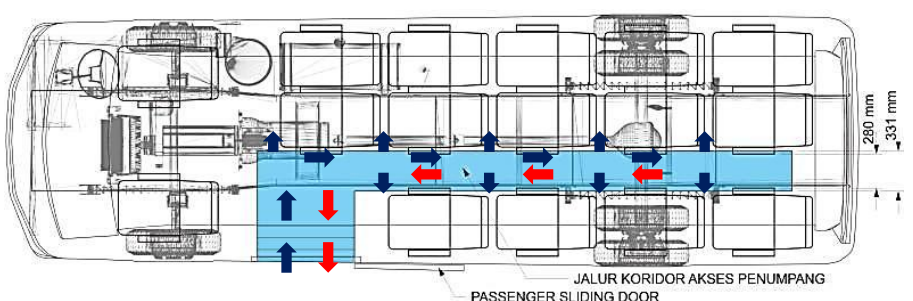

Gambar 5. Analisis Akses Penumpang.

\section{E. Analisis Konfigurasi Bagasi Kabin}

Analisis ini mengikuti dimensi hand-carry barang bawaan penumpang sesuai dengan aturan maskapai penerbangan. Dimensi maksimumnya ialah 560x360x230 mm.

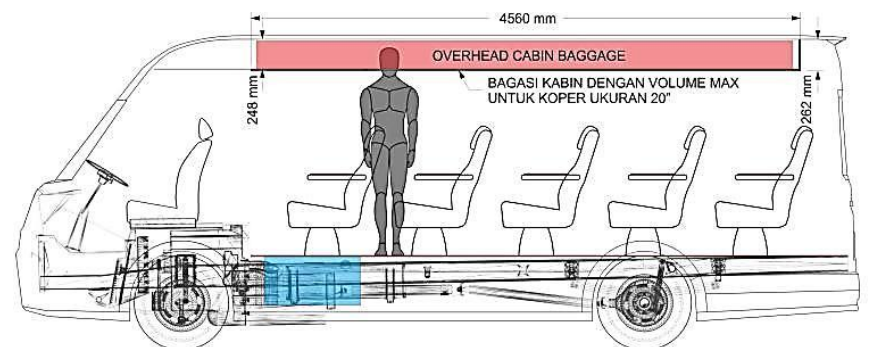

Gambar 6. Analisis Konfigurasi Bagasi Kabin Tampak Samping.

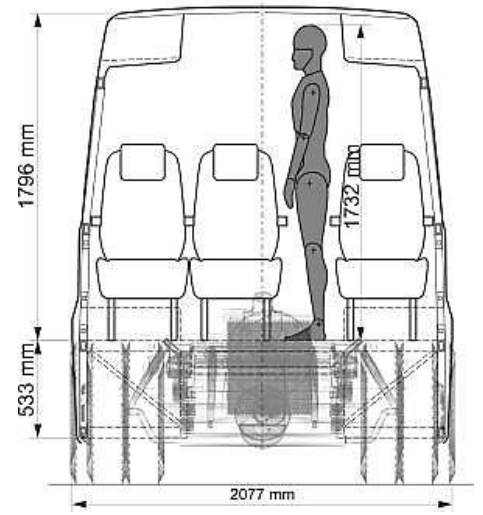

Gambar 7. Cross Section Analisis Konfigurasi Bagasi Kabin. 


\section{C.Analisis Passenger Window Vision}

Analisis ini dilakukan karena kondisi user pra- dan pascapenerbangan yang cenderung jenuh dan kelelahan. Treatment yang diberikan kepada user tersebut ialah suasana relaxing dimana user dapat merasakan driving experience baru dengan adanya panoramic roof dan passenger window berdimensi besar.

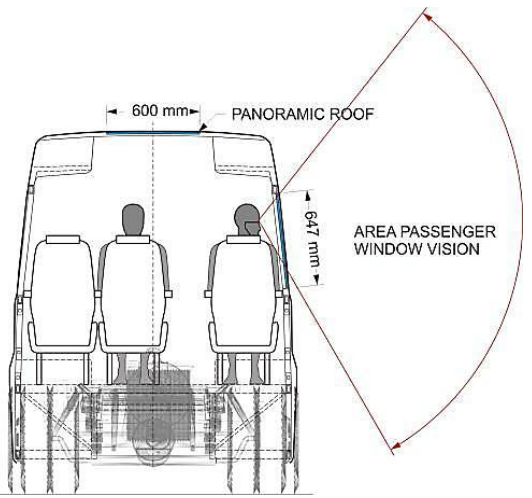

Gambar 8. Analisis Konfigurasi Bagasi.

\section{HASIL DESAIN}

\section{A. Eksplorasi Sketsa}

Eksplorasi sketsa diawali dengan thumbnail sketch bentuk dan proporsi yang mengacu dengan analisa yang telah dilakukan baik teknis dan visual.

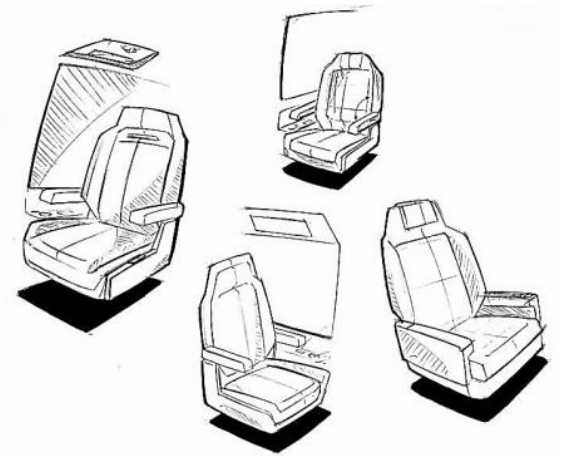

Gambar 9. Sketsa Ideasi Bentuk dan Proporsi.

\section{B. Desain Alternatif}

Sketsa alternatif interior dibuat dengan bentukan, proporsi dan batasan teknis yang telah didapat dari berbagai analisa. Tiga alternatif desain interior dirancang berdasarkan tiga image board yang telah dibuat sebelumnya.

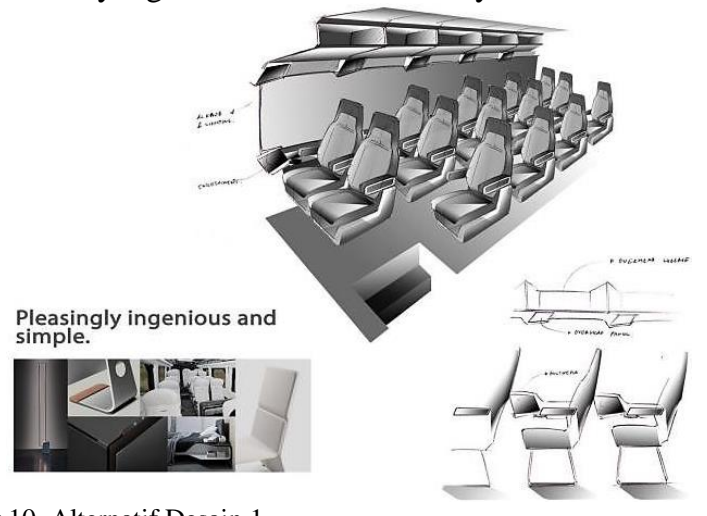

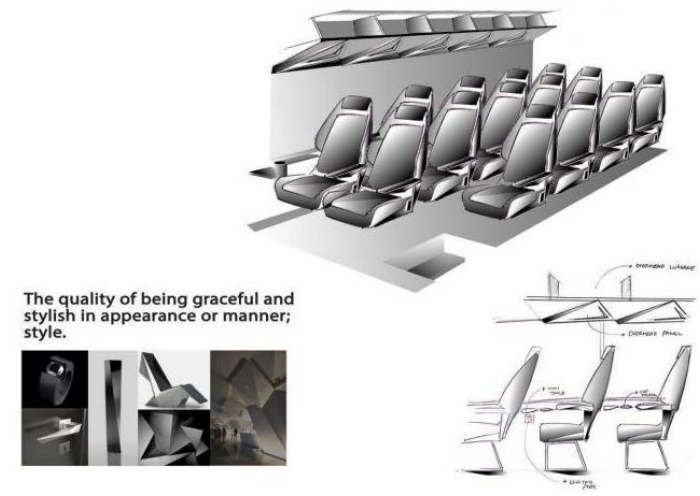

Gambar 11. Alternatif Desain 2.

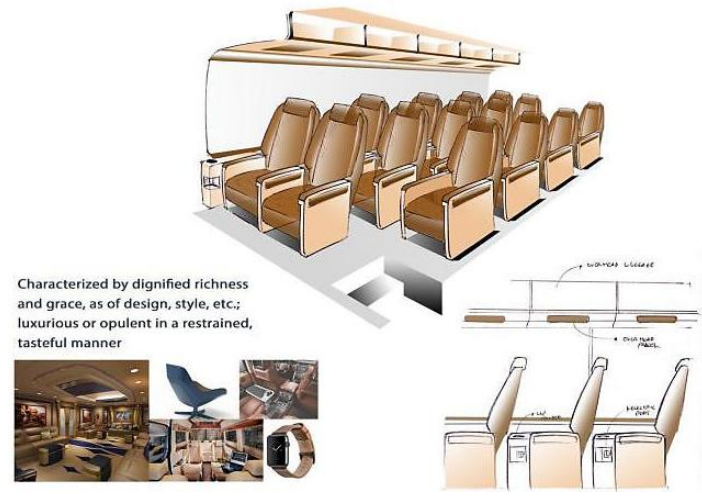

Gambar 12. Alternatif Desain 3.

Dari sketsa alternatif interior yang telah dibuat, dipilih satu desain akhir dimana desain tersebut memiliki nilai dari scoring yang dilakukan sebagai berikut:

Tabel 5.

Scoring Pemilihan Desain Alternatif

\begin{tabular}{|c|c|c|c|c|c|c|c|c|c|}
\hline \multirow[b]{2}{*}{ No } & \multicolumn{3}{|c|}{ Parameter } & \multicolumn{2}{|c|}{ Alt 1} & \multicolumn{2}{|c|}{ Alt 2} & \multicolumn{2}{|c|}{ Alt 3} \\
\hline & Item & W & $\begin{array}{c}\text { Deskrips } \\
\text { i }\end{array}$ & $\begin{array}{c}\mathrm{Ra} \\
\text { te }\end{array}$ & $\begin{array}{l}\text { To } \\
\text { tal }\end{array}$ & $\begin{array}{l}\mathrm{R} \\
\text { at } \\
\mathrm{e}\end{array}$ & $\begin{array}{l}\text { To } \\
\text { tal }\end{array}$ & $\begin{array}{l}\mathrm{R} \\
\text { at } \\
\mathrm{e}\end{array}$ & $\begin{array}{l}\text { To } \\
\text { tal }\end{array}$ \\
\hline 1 & $\begin{array}{l}\text { Relaxing } \\
\text { Feeling }\end{array}$ & 0.5 & $\begin{array}{l}\text { Suasana } \\
\text { Interior }\end{array}$ & 3 & 1.5 & 1 & 0.5 & 3 & 1.5 \\
\hline 2 & $\begin{array}{l}\text { Color } \\
\text { Harmony }\end{array}$ & 0.3 & $\begin{array}{l}\text { Part dan } \\
\text { Panel }\end{array}$ & 4 & 1.2 & 4 & 1.2 & 3 & 0.9 \\
\hline 3 & $\begin{array}{l}\text { Shape } \\
\text { Harmony }\end{array}$ & 0.1 & $\begin{array}{l}\text { Part dan } \\
\text { Panel }\end{array}$ & 3 & 0.3 & 4 & 0.4 & 4 & 0.4 \\
\hline 4 & $\begin{array}{l}\text { Compact- } \\
\text { ness }\end{array}$ & 0.1 & $\begin{array}{l}\text { Assembly } \\
\text { dan } \\
\text { Prod, }\end{array}$ & 4 & 0.4 & 3 & 0.3 & 3 & 0.3 \\
\hline & Total & 1 & & & 3.4 & & 2.4 & & 3.1 \\
\hline
\end{tabular}

Keterangan:

1=Sangat Kurang; 2=Kurang; 3=Cukup; 4=Baik; 5=Sangat Baik

Penilaian skor 1-5 dari pemilihan desain alternatif berdasarkan parameter yang memiliki nilai kepentingannya masing-masing:

1) Relaxing Feeling (0.5)

Treatment atau driving experience yang ditawarkan dari suasana desain interior yang dapat membuat penumpang rileks dan beristirahat dengan baik merupakan aspek terpenting dalam perancangan desain interior minibus shuttle travel rute bandara.

2) Color Harmony (0.3)

Kepaduan warna dari part dan panel interior merupakan impresi pertama yang dirasakan penumpang. Tone warna 
gradasi black-light grey merupakan tone yang memiliki kesan ringan dan santai.

3) Shape Harmony (0.1)

Kepaduan bentuk dari part dan panel interior merupakan impresi selanjutnya yang dirasakan penumpang. Bentukan simple dan tidak rumit dapat memberikan kesan relaxing bagi penumpang.

4) Compactness (0.1)

Parameter ini berhubungan dengan kemudahan assembly part dimana juga berhubungan dengan bentukan shape harmony yang tidak rumit. Selain itu, parameter ini juga mencakup efektivitas ruang secara dimensional.

Keterangan Skor:

\section{Alternatif 1}

Dari segi driving experience yang ditawarkan, alternatif ini menawarkan suasana yang cukup relaxing (3). Untuk kepaduan warna dengan tone black-light grey memiliki nilai yang baik (4). Dari segi kepaduan bentuk terbilang cukup namun tepat sasaran dengan bentukannya yang tidak rumit (3) sehingga memiliki nilai baik pada parameter compactness (4).

2. Alternatif 2

Alternatif ini memiliki desain yang terbilang tense dimana ada driving experience baru yang ditawarkan, namun bentukannya yang rumit membuat nilai suasana relaxing yang sangat kurang (1). Untuk kepaduan warna dengan tone blacklight grey memiliki nilai yang baik (4). Dari segi kepaduan bentuk terbilang baik (4) namun memiliki nilai cukup pada parameter compactness karena bentukannya yang rumit (3).

3. Alternatif 3

Alternatif ini memiliki desain yang memiliki driving experience dengan suasana relaxing yang cukup (3). Untuk kepaduan warna dengan tone beige, alternatif ini memiliki nilai yang cukup (4). Dari segi kepaduan bentuk terbilang baik (4) namun bernilai cukup pada parameter compactness karena memiliki part yang besar dan banyak (3).

\section{Pengembangan Desain}

\section{1) Detil Passenger Seat}

Material passenger seat menggunakan kulit sintetis berwarna hitam pada cover dan bantalan armrest, serta material plastik dengan finishing matte black pada komponen part berbahan fiber / plastik. Detil aksen pada passenger seat menggunakan finishing polished sehingga menambah kesan elegant.
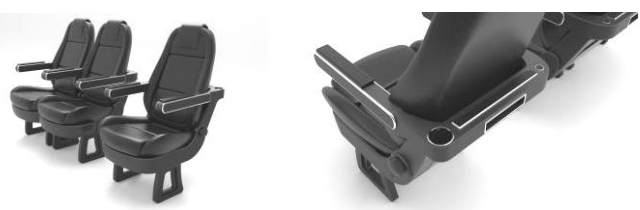

Gambar 13. Gambar Detil Passenger Seat.

\section{2) Detil Interior Cabin}

Tone warna pada interior kabin penumpang merupakan gradasi dari hitam ke light grey. Material flooring ialah pvc laminasi bludru berwarna hitam, sedangkan koridor akses yang luas dilapisi karpet berwarna abu tua. Aksen-aksen baik pada tangga akses, dinding dan bagian atap menggunakan finishing polished sehingga menambah impresi mewah. Dari segi konfigurasi storage, interior ini memiliki overhead baggage yang dapat menampung barang bawaan penumpang dengan ukuran maksimal koper 20 inch.

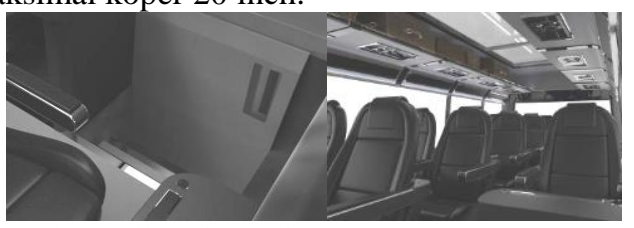

Gambar 14. Gambar Detil Kabin Interior.

\section{3) Fitur Panoramic Roof}

Bagian atap terdapat panoramic roof. Fitur ini dapat memberikan driving experience baru dimana penumpang memiliki akses visual terhadap alam. Fitur ini dapat memberikan suasana relaxing yang menjadi alternatif kegiatan selain beristirahat saat perjalanan berlangsung.

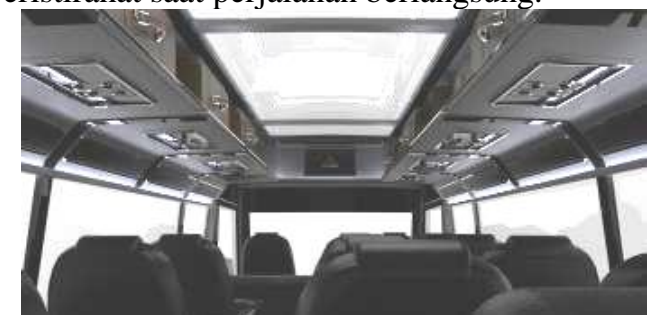

Gambar 15. Gambar Fitur Panoramic Roof.

\section{4) Fitur Indirect Interior Lighting}

Pencahayaan interior menggunakan iluminasi lampu LED sehingga suasana di dalam kabin nyaman untuk beristirahat.

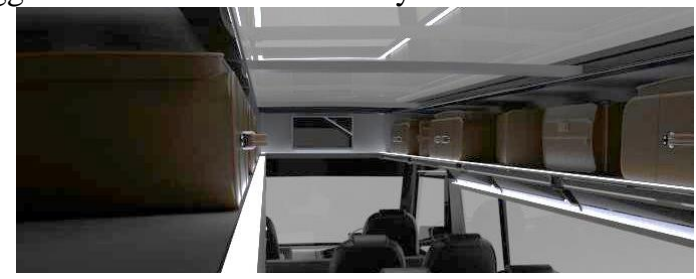

Gambar 16. Gambar Fitur Pencahayaan Interior.

\section{5) Fitur Passenger Seat}

Fitur fold-out tray table dapat digunakan penumpang untuk menunjang berbagai aktivitasnya. Meja lipat memiliki dimensi yang cukup untuk penempatan sebuah laptop atau bahkan untuk menulis dan makan. Tiap kursi juga dilengkapi dengan cup holder. USB charging port dapat digunakan untuk memenuhi kebutuhan daya listrik.

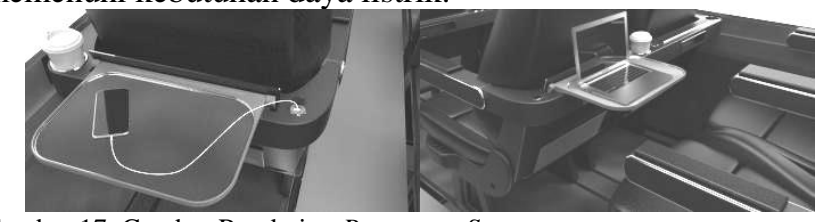

Gambar 17. Gambar Rendering Passenger Seat.

\section{D.Final Desain}

Suasana interior minibus ini memiliki konsep comforting, dimana penumpang dapat beristirahat dengan nyaman. Terdapat suntex blind (tirai jendela) berbahan vinyl-coated polyester pada setiap jendela penumpang yang dapat dibukatutup secara personal. Proporsi jendela penumpang dan panoramic roof yang besar memberikan nuansa natural sehingga pengalaman berkendara akan terasa sangat santai dan membuat penumpang rileks. Demi menjaga cahaya matahari yang masuk, penggunaan kaca film berteknologi tinggi digunakan. 


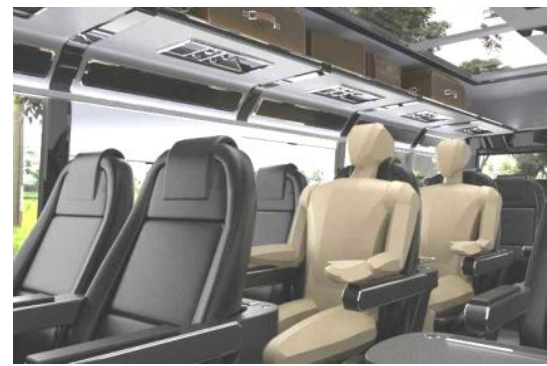

Gambar 18. Gambar Rendering Suasana Interior 1.

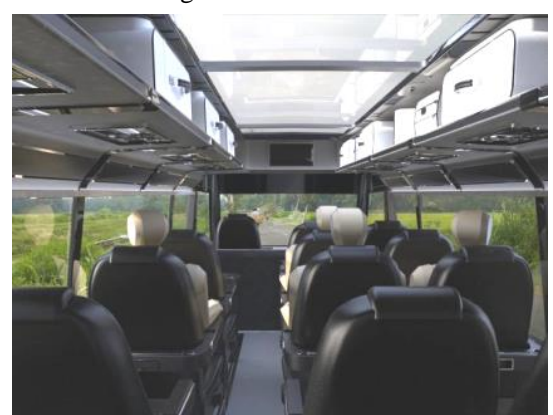

Gambar 19. Gambar Rendering Suasana Interior 2.

\section{KESIMPULAN}

Berdasarkan penelitian yang telah dilakukan, didapatkan kesimpulan dari pengembangan Desain Interior Minibus untuk Shuttle Travel Rute Bandara ialah sebagai berikut:

\section{A. Konsumen shuttle travel dalam pengembangan desain interior minibus}

Konsumen shuttle travel rute bandara memiliki berbagai macam kebutuhan spesifik dimana setelah penilitian ini dilakukan, kebutuhan spesifik tersebut dapat dipenuhi dengan pengimplementasian beberapa fitur dalam pengembangan desain interior minibus ini, seperti:

1) Konfigurasi

a. Jarak antar kursi penumpang yang memenuhi nilai proxemics. b. Akses pintu dan koridor penumpang yang luas dan mudah diakses.

c. Dimensi storage pada interior yang sesuai dengan kebutuhan.

d. Dimensi bagasi yang sesuai dengan kebutuhan.

2) Fitur Penumpang

a. Ergonomic Passenger Seat with Armrest

b. Fold-out Tray Table

c. Cup Holder

d. USB Electrical Port

e. Free Wi-Fi

f. Personal Storage

g. Personal Adjustable AC Knob

h. Personal Reading Lamp

$i$. Personal Suntex Blind

\section{B. Konsumen shuttle travel kondisi post-flight}

Konsumen shuttle travel rute bandara dengan kondisi postflight membutuhkan desain interior kendaraan dengan perlakuan atau treatment khusus. Treatment tersebut berupa suasana interior dengan driving experience yang secara psikologis dapat memenuhi ekspektasi user, yaitu:

1. Penerapan warna dan material yang nyaman dan hangat.

2. Penerapan bentuk komponen interior yang simple dan tidak rumit.

3. Penerapan iluminasi pada pencahayaan interior sehingga nyaman untuk beristirahat.

4. Penerapan panoramic roof yang menimbulkan suasana relaxing ketika melihat pemandangan alam.

5. Penerapan fitur penumpang personal dan free Wi;Fi yang dapat menunjang aktivitas bekerja.

\section{DAFTAR PUSTAKA}

[1] D. Y. D. Cholil, “Analisis Preferensi Konsumen Jasa Shuttle Travel Trayek Jakarta-Bandung," 2014.

[2] B. Suhardi and T. Pilihanto, "Perancangan Ulang Kursi Bus AC Patas Ditinjau dari Aspek Ergonomi," in National Confrence on Applied Ergonomics, 2009. 